\title{
The Application of Hisba Moral Enhance Students' Discipline
}

\author{
Dr. Mardzelah bt. Makhsin
}

Universiti Utara Malaysia; mazfaniy@uum.edu.my

\author{
Dr. Nuruwahida bt Azid@Aziz \\ Universiti Utara Malaysia; nurulwahida@uum.edu.my \\ Mohamad Fadhli Ilias
}

Universiti Utara Malaysia; uztazfadhli@gmail.com

\section{Doi:10.5901/mjss.2016.v7n1s1p234}

\section{Abstract}

Hisba moral consciousness through Islamic Education teachers are agents of socialization. It is very important in influencing student self-esteem application to practice the good habit for establish consistency in the nature of the discipline. It can also avoid misconduct and bad thing in Islamic life. The goal is to produce students who have the moral consciousness capable of strengthen the excellence of self, family, country and religion. Hisba application of Islamic Education teachers aims to change a person's character and behavior into a more positive direction to achieve certain goals in life and develop the full potential of human beings. This article explains the practice of hisba teacher education and disciplinary problems in secondary school students. Methodology of this study uses a qualitative approach through interview to the teachers and students. The results showed that application of hisba among teachers have a significant relationship with a appreciation of the character of human potential construction agreement involving the promise of the heart, behavioral observation, accountability practice, spiritual reward, struggle of desires and soul purification. Students who have the potential to maintain a controlled self-esteem with the compliance and avoid discipline concerned with delinquency in schools.

Keywords: Teacher; Moral consciousness; Self-esteem; Islamic Education; Discipline

\section{Introduction}

The goal of Islamic education is to produce good human beings and a good deed (Ibn Khaldun, 1993; al-Attas, 1978; Nasir, 2002), people who have a personal perfection (Muhammad Uthman, 1987; Abdul Rahman, 1995), people were aware of his relationship with God, nature and man (al-Shaybani, 1975; Zawawi, 1996), disclose the nature of existence as a servant of God and inheritors of the earth , receive the benefits of the revelations of Allah, build attitude to look at life through the eyes of religion and learn to open our hearts to receive the light and grace of God is immortal (Shaikh Abdul Mabud, 1999; Nasir, 2002). Accordingly, the human generated through proper Islamic education is a man whose personal and noble character in line with the objectives of the mission of the Prophet (al-Shaybani, 1975). The results reflected the objectives of Islamic education through the application of comprehensive and integrated growth in private student (al-Shaybani, 1975) with the integration between faith, knowledge and good deeds (Mohd Kamal, 1979), appreciation and sensitivity towards Islam (Syed Ali Ashraf, 1997 ), as well as the appreciation of noble character in an individual student (al-bout, 1961; al-Abrasyi, 1974; al-Qabisi in al-Nai'my, 1994; Jalaluddin \& Usman, 1994; Azhar, 2006). These objectives enable students to live as best as possible, rooted in Islamic faith (iman and insan) at all times to achieve happiness in this world and the Hereafter (Mohd Kamal, 1979; Jalaluddin \& Usman, 1994; Mohd Alwi, 1997; Azhar, 2010).

However, the problem related with the moral blanks of the educational goals described above, as Muhammad Iqbal (in al-Nadwi 1987) argued that the diminution in value is a symptom of the loss of moral considerations the human potential; arising very wide the gap between the physical and spiritual, reason and faith, knowledge and faith; lost selfesteem, confidence is weak and hopeless; excluded from the religious beliefs and God; a shallow reasonably and the hard hearts from the truth; religion; political; intellect and was concentrated materialism; and life shrouded in resistance and shortcomings in accordance with Islamic law. There are various symptoms of diminution in value character. Among 
the various types of crime in the form of immoral acts committed by individuals in the community among the students (Wan Mohd, 2005; others, 2008; Syed Omar, 2009). In addition, the symptoms of character decline is also related to the issue of lack of interest in the teaching of Islamic education identified through symptoms Islamic education students skip class than other subjects, student participation is less than the participation in the activities of other subjects, do not pay attention next time Islamic education classes class lectures held by the teacher, the students do not complete the task of education to various reasons, students who are trying to find additional resources to increase understanding and knowledge in Islam and less to participate in the activities of extra-curricular in Islamic Education. In this context, the implementation of ombudsmen as a mechanism of control and supervision is the best alternative in guiding the youth to build a noble character and in line with the nature and requirements of the Islamic Education. Hisbah practice is an attempt to solve the problem of lack of student interest in understanding the appreciation of Islamic education in life. Instead of students who can not keep an eye themselves in understanding the knowledge of Islamic Education in understanding the practical impact on delinquent behavior. Problematic behavior is have links with diminution in value moral encouragement the criminal involvement vices that destroy human beings (Syed Omar, 2009).

Hisba is a moral consciousness control system that functions in an effort to realize the National Philosophy of Education, by emphasizing the potential of a comprehensive and integrated to create a balanced and harmonious intellectually, spiritually, emotionally and physically by faith and devotion to God. This effort is designed to produce Malaysian citizens who are knowledgeable, competent, virtuous, responsible and capable of achieving well-being and contribute to the betterment of the family, community and country. Hisba morality in Islam is one very important aspect in the development a Muslim who has a perfect human personality, according to al-Quran and al-Sunnah (Zaharah, 2008). This aspect has an important role in building consciousness character, especially in the early stages of adolescents are often faced with a crisis of self-identity, and most of them are easy to fall into the social ill which are in crisis and unhealthy life. The study was conducted in order to identify the practice of hisba as practice-oriented behavior control to compliance Islam practiced by teachers. Also to review the extent of this practice affect the appreciation of moral education students in understanding Islam. Self Hisba consists of six components in the intelligent potential in Islam which consists the promise of heart (musyaratah), observations of behavior (muraqabah), practices reflection (muhasabah), spiritual reinforcement (muaqabah), struggle of desires (mujahadah) and purification of the soul (muatabah). Hence, this study is very important in obtaining an input in improving teaching and learning of Islamic Education in order to produce students who have admirable personality.

\section{Objective}

The aim of this study was to identify practices of Hisba among Islamic Education teachers to appreciation of moral influence students toward dealing with misconduct and indiscipline in schools. This study also aims to identify the relationship between the Hisba practice teacher of Islamic Education to enhance the students from the aspect of the appreciation of moral discipline, the influence of parents, teachers and peers. In addition, this study able to explain how a teacher should make the Hisba as obedience to good practice and keep clear of bad deeds. The results of this research will provide exposure to the teachers about the importance of hisba control which can raising student consciousness towards achieving the excellence of noble values in their life.

\section{Method}

In this study, researchers selected a quantitative approach using design and descriptive survey to identify the practice and appreciation of moral the Hisba student teacher in the teaching and learning of Islamic Education. The method of quantitative surveys to get data on teacher practice and appreciation of moral the Hisba students using questionnaires as the primary instrument. Skager and Weinberd (1979) believes that the questionnaire is an instrument often used in the research. Among the reasons survey method through a questionnaire used to measure the opinions, attitudes and behavior (Ary et. Al, 2002). Even Kerlinger (1986), to explain that the method through surveys can also see how independent variables are manipulated on the dependent variable. Therefore, this study uses quantitative methods to examine the relationship between independent variables and the dependent variable (Bogdan and Biklen, 2003). In addition, this study also was supported by interviews with the Islamic Education teachers and students form four involved in misconduct to know in more detail about the practice teacher the Hisba in improving students' appreciation of moral. The result of the interview will describe the findings of the questionnaire with more precise argumentation regarding the practice the Hisba Islamic Education teachers in enhancing the student moral appreciation.

The study population consisted of four students who have followed the teaching and learning of Islamic education 
from grade one to grade three. Form Four student participation in this study were selected on the basis that they have passed the age of puberty maturity of over 15 years has been defined as the age limit for taking responsibility law (Abdullah Nasih 1984). According to Hassan Langgulung (1995), among the best methods to use in studies relating to the personality and character is a self-assessment among involved. In this context, the students form four assumed to be able to assess themselves and be able to distinguish the good from the bad. They also identified the process of learning experiences through the curriculum of Islamic education for nine years at primary school level (KBSR) and secondary (ICSS). Form Four student experience for nine years to give the impression that they are able to assess themselves with the teachings of Islam appreciation obtained through Islamic education curriculum (Azhar 2006).

Researchers chose populations by zone and country specific as to the homogenous or uniform population of the same age in terms of age and the teaching and learning based on Islamic Education curriculum in line at the Ministry of Education. Researchers have divided the zones by the states in Malaysia involving the Northern Zone, Penang, Selangor South Zone, East Zone, Kelantan, West Zone, Johor. The sample consisted of 1300 students and 300 teachers from secondary schools in Malaysia.

\section{Findings}

The findings, which consists of qualitative findings through by descriptive in quantitative and case study in qualitative results.

\subsection{Descriptive Result}

Descriptive analysis is a comprehensive data parsing technique that aims to provide an initial overview of the respondents' profile based on frequency, percentage, mean and standard deviation. Accordingly, the data are analyzed interpreted according to the dimensions of the mean score of affective behavior as shown in Table 1.

Table 1: Mean Score Interpretation Affective Dimension Behaviors

\begin{tabular}{cc}
\hline Skor $\min$ & Interpretation \\
\hline $4.01-5.00$ & Highest \\
$3.01-4.00$ & High \\
$2.01-3.00$ & Low \\
$1.01-2.00$ & Lowest \\
\hline
\end{tabular}

Scale response to the Questionnaire

In the context of this study, respondents were given a choice of answers from 1 to 5 Never (1), occasionally (2) Sometimes (3), Always (4) and Very Frequent (5). Based on the study Kamarulzaman et al (2009), the researcher justify the scale of the frequency of the practice and appreciation of moral hisba students are given a score of Never (1) as not once did the practice of hisba, occasionally given a score (2), which is 1-2 times a month, sometimes with a score of (3) which is 3-4 times a month, often given a score (4) was 5-6 times a month and very often given a score (5) which is more than 7 times a week. Table 3.8 explain the interpretation of the score of five points Likert scale used in the questionnaire hisba and moral appreciation of high school students.

Table 2: Mean Score od Hisba Moral Practice

\begin{tabular}{ccc}
\hline Score & Practiced & Frequency \\
\hline 1 & Once while & Once in a lifetime \\
2 & Seldom & $1-2$ times a month \\
3 & Sometimes & $3-4$ times a month \\
4 & Always & $5-6$ times a month \\
5 & Very often & More than 7 times a week \\
\hline
\end{tabular}

Descriptive analysis of the practice of hisba among the teachers in Islamic education to enhance students moral are described in the following table: 
Table 3: Descriptive Results

\begin{tabular}{|c|c|c|c|c|c|c|c|}
\hline Pernyataan & 1 & 2 & 3 & 4 & 5 & Min S.P & Frequency \\
\hline $\begin{array}{l}\text { motivate students with the story of the Prophet Muhammad } \\
\text { delivering a the benefits and educate people with noble character }\end{array}$ & $\begin{array}{c}5 \\
(0.3 \%)\end{array}$ & $\begin{array}{c}53 \\
(3.0 \%)\end{array}$ & $\begin{array}{c}163 \\
(9.1 \%)\end{array}$ & $\begin{array}{c}450 \\
(25.2 \%)\end{array}$ & $\begin{array}{c}1114 \\
(62.4 \%)\end{array}$ & 4.470 .80 & High \\
\hline demonstrate good practice to be friendly and take care of students & $\begin{array}{c}13 \\
(0.7 \%)\end{array}$ & $\begin{array}{c}69 \\
(3.9 \%)\end{array}$ & $\begin{array}{c}196 \\
(11.0 \%)\end{array}$ & $\begin{array}{c}445 \\
(24.9 \%)\end{array}$ & $\begin{array}{c}1062 \\
(59.5 \%)\end{array}$ & 4.390 .88 & High \\
\hline encourage students to adhere to the teachings of Islam & $\begin{array}{c}13 \\
(0.7 \%)\end{array}$ & $\begin{array}{c}64 \\
(3.6 \%)\end{array}$ & $\begin{array}{c}222 \\
(12.4 \%)\end{array}$ & $\begin{array}{c}512 \\
(28.7 \%)\end{array}$ & $\begin{array}{c}974 \\
(54.6 \%)\end{array}$ & 4.330 .88 & High \\
\hline $\begin{array}{l}\text { monitor and control the behavior of student behavior in order to } \\
\text { obedient with school rules }\end{array}$ & $\begin{array}{c}10 \\
(0.6 \%)\end{array}$ & $\begin{array}{c}54 \\
(3.0 \%)\end{array}$ & $\begin{array}{c}240 \\
(13.4 \%)\end{array}$ & $\begin{array}{c}495 \\
(27.7 \%)\end{array}$ & $\begin{array}{c}986 \\
(55.2 \%)\end{array}$ & 4.340 .86 & High \\
\hline $\begin{array}{l}\text { delivers knowledge by the easy to understand and ensure that } \\
\text { students like the Islamic Education }\end{array}$ & $\begin{array}{c}7 \\
(0.4 \%)\end{array}$ & $\begin{array}{c}35 \\
(2.0 \%)\end{array}$ & $\begin{array}{c}165 \\
(9.2 \%)\end{array}$ & $\begin{array}{c}473 \\
(26.5 \%)\end{array}$ & $\begin{array}{c}1105 \\
(61.9 \%)\end{array}$ & 4.480 .77 & High \\
\hline $\begin{array}{l}\text { listen to students' problems and solve problems that students facing } \\
\text { as a matter of discipline and education }\end{array}$ & $\begin{array}{c}38 \\
(2.1 \%)\end{array}$ & $\begin{array}{c}131 \\
(7.3 \%)\end{array}$ & $\begin{array}{c}315 \\
(17.6 \%)\end{array}$ & $\begin{array}{c}547 \\
(30.6 \%)\end{array}$ & $\begin{array}{c}754 \\
(42.2 \%)\end{array}$ & 4.041 .04 & High \\
\hline encouraging students to speak the truth and be honest in life & $\begin{array}{c}10 \\
(0.6 \%)\end{array}$ & $\begin{array}{c}31 \\
(1.7 \%)\end{array}$ & $\begin{array}{c}141 \\
(7.9 \%)\end{array}$ & $\begin{array}{c}444 \\
(24.9 \%)\end{array}$ & $\begin{array}{c}1159 \\
(64.9 \%)\end{array}$ & 4.520 .76 & High \\
\hline preachers are delivering a good and avoid evil & $\begin{array}{c}6 \\
(0.3 \%)\end{array}$ & $\begin{array}{c}53 \\
(3.0 \%)\end{array}$ & $\begin{array}{c}162 \\
(9.1 \%)\end{array}$ & $\begin{array}{c}440 \\
(24.6 \%)\end{array}$ & $\begin{array}{c}1124 \\
(63.0 \%)\end{array}$ & 4.470 .81 & High \\
\hline $\begin{array}{l}\text { showing compassion and caring for students and always wish to } \\
\text { become successful students }\end{array}$ & $\begin{array}{c}16 \\
(0.9 \%)\end{array}$ & $\begin{array}{c}67 \\
(3.8 \%)\end{array}$ & $\begin{array}{l}161 \\
(9.0 \%)\end{array}$ & $\begin{array}{c}442 \\
(24.8 \%)\end{array}$ & $\begin{array}{l}1099 \\
(61.6 \%)\end{array}$ & 4.420 .87 & High \\
\hline $\begin{array}{l}\text { delivers knowledge with sincere and always advise students with } \\
\text { good words and showing model of noble values }\end{array}$ & $\begin{array}{c}7 \\
0.4 \%) \\
\end{array}$ & $\begin{array}{c}34 \\
(1.9 \%) \\
\end{array}$ & $\begin{array}{c}125 \\
(7.0 \%) \\
\end{array}$ & $\begin{array}{c}353 \\
(19.8 \%) \\
\end{array}$ & $\begin{array}{c}1266 \\
(70.9 \%)\end{array}$ & 4.590 .74 & High \\
\hline Total & & & & & & 4.410 .84 & High \\
\hline
\end{tabular}

The findings in Table 3 describe all items in hisba teacher interpreted as a high score. There are $87.6 \%$ of students believe that the Islamic Education teachers always and very often motivate students (mean $=4.47, \mathrm{SP}=0.80$ ), $84.4 \%$ of students believe that the Islamic Education teachers are always friendly and very often behave with students (mean = $4: 39, \mathrm{sp}=0.88), 83.3 \%$ of students believe that the Islamic Education teachers always and very often oversee the behavior of students (mean $=4: 33, s p=0.88$ ), $82.9 \%$ of students believe that the Islamic Education teachers always and very often control the discipline of students in the classroom (mean $=4: 34, \mathrm{sp}=0.86), 88.4 \%$ of students believe that the Islamic Education teachers always and very often to explain in simple (mean $=4: 48, \mathrm{sp}=0.77$ ), $72.8 \%$ of students believe that the Islamic Education teachers always and very often hear the problems of students (mean $=4: 48, s p=$ 0.77), $89.8 \%$ of students believe that the Islamic Education teachers always and very often encourage students to speak the truth (mean $=4: 48, \mathrm{sp}=0.77$ ), $87.6 \%$ of students believe that the Islamic Education teachers always and very often carry out responsibilities as preachers (mean $=4: 48, \mathrm{sp}=0.77$ ), $86.4 \%$ of students believe that the Islamic Education teachers always and very often is compassionate and not favoritism (mean $=4: 48, \mathrm{sp}=0.77$ ), and $90.7 \%$ of students believe that the Islamic Education teachers always and very often ask students to practice good and avoid evil (mean = $4: 48, s p=0.77$ ).

Descriptive findings explain that the teachers do practice hisba are high (mean $=4: 41, s p=0.84$ ). These results illustrate that religious teachers carry moral values hisba in the implementation of religiosity (Ibn Khaldun in Al-Na'imy 1994; Mohd Kamal, 1988, 1994; Nik Mohd Rahimi and colleagues, 2002; Asmah \& Zulekha 2004; Zaizul et .al 2011), the teaching practices of effective teachers of Islamic Education (Ibn Khaldun in Al-Na'imy 1994; Ghulam 1999), teacher as a model leader with high morals (Mohd Kamal 1988; Nor Azam 2005), advise and encourage to do good and avoid evil (Mohd Kamal 1988; Mohd Arif 1998; Nik Mohd Rahimi et al., 2002; Che Noraini 2005; eventually \& Shamsina 2011) and stressed the Islamic character who was educated in Islam (Mohd Kamal 1988; Nik Mohd Rahimi et al., 2002 ; Che Noraini 2005; Shamsaadal \& Abdullah 2006; Roslan \& Nosiah 2007; Zaizul 2011).

\subsection{Case Study Result}

The results of the case study through interview and written descriptive profile cases. The case describes the problems of discipline and misconduct committed, the source of misconduct, relationships with parents, friends and teachers as well as the views of respondents to the practice of Islamic Education teachers hisba. Example the case:

Respondents aged 16, is the son of the 6th of 9 siblings. Derived from Kota Bahru, Kelantan. Mother is a housewife and my father is self-employed and family income is RM500.00 per month.

a) The issue of the Disciplinary and Misconduct: Form of misconduct that have been done have sex out of wedlock after Raya ago. The man in the house, a neighbor of the same village and the boyfriend. But have 
never been involved with misconduct in schools.

b) Cause committed misconduct: I think of myself not as perfect as the other students because of disability in the legs. Some people scoff and ridicule often particularly classmates. In my spare time (afternoon or evening) I like to spend time with the internet. I think the act of misconduct can relieve stress.

c) Relationship with Parents: My relationship with parents and other family members usually only for their own and do things just sometimes just asking things about themselves and school. Things that have always been discussed by the parents about school, friends and themselves.

d) Relationship with Peers: I am also meeting with a friend. If I push his will, he will get angry and do not want to be friends. There is also a friend of websites I always visit Facebook and wechat to get rid of boredom due to the pressure of school work and things that happen to yourself. For example problems of friends and family issues are often quarreled. This is because the father had just stopped working. I always stress at school and when out with friends. If pressed, I always reflective in the classroom and the school does not complete the work assigned by the teacher. If depressed sitting in a room alone. If you are at school I refer friends, scholars and teachers who most closely that of Mrs Norizan, my adoptive mother. If I increased stress, I always shouted and release my tension to his sister and a friend.

e) Relationship with Teachers: I like the history teacher Mrs. Azilah because he is a good, easy-to-understand teaching as a point and also a note. By providing only important point to make it easier for students. But there are also teachers who likes to get angry, but anger is there in the advice given. There is also a fine teacher of squats. Teachers are always greeted with the advice gently said that next year all students will take the examination to be learned chic-chic. Cannot wear tight pants, short scarves. The school will continue to take action against students who do not comply with these regulations. I'm always be careful in school, worry scolded and also penalty.

f) The view of the practice of Islamic Education Teachers about Hisbah: Religious teacher attempt to advise students to be diligent studying. Before classes always went to see Mrs. Faridah. Religious teacher always remind students to pray immediately when the time for prayer but depend on the student to do so or not, encourage students to read the Quran every day, encourage students to practice moral behavior when the teaching of Islamic Education, namely by doing charity and although a little donation, ask students to leave the act which led to the vices and immorality, emphasize teaching obey the commandments of God and away from the ban but Allah; Allah, advised students to make friends with a friend who remember Allah, sent choosing good friends - so top ourselves whether to choose good friends or bad man. Religious teacher explain to students about the importance of obeying and loving parents and teachers because heaven under the feet of mothers and do not rudely to parents. Religious teacher also educate students to keep talking and not offend others and encourages students to provide assistance to the less fortunate. While donations are only 10 cents. Religious teacher also advise students to read 'Inna innalillahiwa ilaihiraajiuun' at the end of the class should hear any news of the death or misfortune. Religious teacher always taught me with gratitude on God's gift of sustenance. For example on the air and nice granted during the life of this life. Of course, religious teacher considering and ask students to read 'Bismillah' and pray before and after meals and thanks to a provision which God and to take lawful and balanced. This is because the food you eat will become flesh and blood. Above religious teacher always apply the practice of praying to God before and after getting success. We have to believe in God after we have done efforts for the better in the life.

g) Discipline Problem: From interview, the respondents had committed a very serious offense, namely by having sex outside marriage is wrong in law and religion. Islam strictly prohibited from its followers from committing of adultery. However, it is still not known by the school and both parents still do not know. The symptoms of free sex among teenagers especially students who hold a 16 -year-old rising. They are most at risk involved in discipline problems including trying to have sex for the first time. This is a serious problem affecting teenagers nowadays and the involvement of girls in free sex even unknown to guard the school.

He respondent states that she is aware that as a Muslim should not have sex before marriage, but the desire to caused her unable to have sex for free to prove of love. Although the respondent always remember religious teacher message to be good human beings and live in obedience to the rules of Islam.

Thus the role of all parties, especially the Islamic Education teachers in applying the moral hisba control is very important to high school students realize and appreciate adherence Islamic way of life. 


\section{Discussion}

The findings explain that the Islamic Education teachers always apply the values the good in each student based on the true teachings of Islam and holistic. From the results, the Islamic education teachers are always trying to remind students about the responsibilities that should be implemented as a Muslim in order to succeed in this world and hereafter. This is in line with our responsibility as a teacher is complex. Teachers are responsible for delivering lessons and perform a variety of roles. Therefore, teachers must demonstrate good moral character so all delivered easily followed and adhered to by students. This is because effective teaching techniques that occurs when students easy to accept, appreciate and can apply learning in an atmosphere of daily life (Mardzelah 2012). According to Abdullah (1989) that delivers the effectiveness of knowledge need that teachers have the properties of leading personalities, leadership qualities and character of perfectly. Prophet Muhammad taught Muslims to be the best method, as a good teacher must have a certain gentleness and away from the demands and desires to be forgiving when educating. The nature and characteristics of a teacher is to have a noble character as taught by the Prophet delivering a knowledge and guiding people towards goodness to become Caliph of Allah (Ab. Halim Mohamad Khairul 2010). The effectiveness of teaching is also linked to the teacher's role as a catalyst in the growth and development of students, mentors and models, learning and decisionmakers in the use of the existing opportunities for student welfare. Teachers also have a variety of roles in addition to educators as a facilitator, consultant or consultants, managers, researchers, counselors, models and agents of change. The teacher as an educator, a teacher of the knowledge with emphasis on practice values-based religion (Ab. Halim \& Zarin, 2001)

According to al-Ghazali (2004), there are eight responsibilities of teachers, the search for knowledge, practice science, love of students, teaching with the intention to save students from suffering hereafter, Learning Messenger SAW, does not consider himself the most meritorious students, emphasizing the reward and do not want to defaults of responsibility (Abdul Salam 2003). Mohd Azam (2009) also states that there are four areas of responsibility of a teacher, that is the education, parents, society and the State and responsibility towards colleagues and the teaching profession. In addition, Kamarul Azmi and Ab. Halim (2010) explain that there are five characteristics of Muslim teachers based on their duties and responsibilities. Five its teachers are teachers as mudarris (instructor), muaddib (former manners), murabbi (growing up, maintain and educate so noble), mursyid (to guide) and mu'allim (instructor or teacher or educator).

The main task of the teacher is trying to develop the full potential of students, whether potential psychomotor, cognitive and affective as described in the Philosophy of Islamic Education. Therefore, teachers in the education system must meet all the demands of Islam gain or role models to society and become agents of change in society through formal or informal education (Ab. Halim Mohamad Khairul 2010). Teacher behavior reflects their advantage to be accepted by the students. This is because each teacher behavior has always been a concern and a role model for students. In this context, the teacher was given a high position and esteem as al-Ghazali (2004) explains that the position of teacher notch below the rank of a prophet and apostle. This position is given in accordance with the occupation or profession of teachers who are trying to educate people to the right path and seeks to prohibit students from committing crimes. Thus, the duties and responsibilities of the teacher is to inherit the task of the Messengers that continue to enlighten people to believe and work with Islamic law (Mardzelah, 2012). The duties and responsibilities of each teacher preaching should be fulfilled so that teachers are able to produce students with good character and noble attitude to realize the excellent human capital.

\section{Conclusion}

This study has reviewed the practices of hisba moral in enhancing appreciation of the moral character of secondary school students. The results of the study in an interview the students, emphasizing the values of Islam has been presented by the teacher of Islamic education. In this context, students should be immunized spirit through the practice of hisba to enhance the moral consciousness for making the self-discipline. Therefore application of hisba moral by Islamic education teachers play a vital role in the process of educating and training the mind, physical, spiritual and emotional human resource-based al-Quran and Sunnah to produce individuals capable of shouldering good responsibility accountable by God for the people to enlighten this nature for the happiness of his life in this world and hereafter.

\section{Acknowledgements}

The research reported in this article is a part of Research Acculturations Grant Scheme RAGS grant (code:12851) supported from Malaysian Ministry of Education (KPM). 


\section{References}

'Abd Allah Muhammad 'Abd Allah. 1996. Wilayat al-Hisbah fi al-Islam. al-Qahirah: Maktabat al-Syu'ara'.

Ab. Halim Tamuri. (2000). A study of the students' knowledge of akhlaq in the Malaysian secondary schools (with special reference to the Islamic education KBSM). Tesis PhD, University Of Birmingham.

Ab. Halim Tamuri \& Zarin Ismail. (2001). Persepsi pelajar muslim terhadap konsep akhlak. Kertas kerja Persidangan Kebangsaan Pendidikan Moral dalam dunia Globalisasi. Unniversiti Malaya, Fakulti Pendidikan, 23-25 Mei.

Ab. Halim Tamuri, Adnan Yusopp, Kamizah Osman, Shahrin Awaluddin, Zamri Abdul Rahim dan Khadijah Abdul Razak. (2004). Keberkesanan kaedah pengajaran dan pembelajaran Pendidikan Islam ke atas pembangunan diri pelajar. UKM: Fakulti Pendidikan (laporan penyelidikan tidak diterbitkan kod GG002/2004).

Al-Ghazali, al-Imam Abu Hamid Muhammad ibn al-Ghazali.(1988). Ihya' 'Ulum al-din.Jil. 1-8. Kuala Lumpur: Victory Ajensi

Al-Ghazali, al-Imam Abu Hamid Muhammad ibn al-Ghazali. (t.th). Ihya' 'Ulum al-din. Jil. 1-5. Misr: al-Maktabah al-Taufiqiyyah.

Amy Chak. 2006. Dialogue on 'Reflecting on the self'. Relective Practice Journal. Vol.7. No.1, pp. 55-57. February.

Anderson, E. L. 1994. The Effect of Forental Involvement on Academic Achievement. Woldan University, United States.

Aswati Hamzah. 2007. Satu kajian skema taakulan akhlak dalam kalangan murid Melayu. Pulau Pinang: Penerbit Fakulti Pendidikan, Universiti Sains Malaysia.

Auni Abdullah. (2000). Hisbah Dalam Pentadbiran Negara. Kuala Lumpur: IKDAS SDN BHD.

Azhar, Ahmad. (2006). Strategi Pembelajaran Pengaturan Kendiri Pendidikan Islam dan Penghayatan Akhlak Pelajar Sekolah Menengah di Sarawak. Tesis Doktor Falsafah. Fakulti Pendidikan Universiti Kebangsaan Malaysia, Bangi.

Bandura, Albert. 1977. Social Learning Theory. New Jersy: Prentice-Hall.

Basya, Hasan 1966. al-Funun al-Islamiyyat wa al-Waza'if 'ala al-'Athar al-'Arabiyyat,- Kaherah: Dar al-Nahdah al-Arabiyyah.

Battle, James 1984. Promoting Self-Esteen Achievement and Well Being: An Effective Instructional Curriculum for All Levels. Edmonton: James Battle \& Associates.

Bensaid, Benaouda. 2008. Towards a Model of Da'wah in Contemporary Societies: The Case of Shaykh Muhammad Al-Ghazali (19171996). Ph.D. Dissertation. McGill University (Canada). http://proquest.umi.com.eserv.uum.edu.my/ [22 Januari 2012].

Bernstein, B.B. 1971. Class, Codes and Control. London: Routledge \& Kegen Paul.

Bloom, S. B. 1976. Human Characteristic And School Learning. New York: McGraw- Hill.

Bogdan, R.C \& Biklen, S.K. 2003. Qualitative Research for Education: An Introduction to Theories And Methods (4th Ed.). New York: Pearson Education Group.

Brander, Nantheniel. 1987. How to Raise Yourself Esteem. New York: Bentam Book.

Briggs. D.C. 1987. Celebrate Yourself: Enchancing Your Own Self Esteem. New York: Doubleday.

Brocher Joel.1998. Self-Esteem at Work: Research, Theory and Practice. Lexington: Lexington Book.

Brockett, R. G., \& Hiemstra, R. 1990. Self-direction in learning: Perspectives on theory, research, and practice. New York: Routledge.

Burns, R.B. 1979. The Self Concept $n$ Theory, Measurement, Development and Behaviour. London: Longman.

Burns, R.B. 1982. Self Concept Development and Education. London: Holt, Rinehart and Winston

al-Buoti, Muhammad Sacid Ramadhan. 1961. TAjribah Al-Tarbiyyah Al-Islamiyyah fi mizan Al-bahth. Damsyiq: Al-Maktabah AlUmmawiyyah.

Cephas, Joan E. 2011. The relationship between religious commitment and academic achievement among African-American high school students. EdD Dissertation. United States: Virginia Regent University,

Chamot, A. U., Barnhardt, S., El-Dinary, P. B. dan Robbins, J. 1999. The learning strategies handbook. New York: Pearson Education.

Kamarul Bahariyah Salleh. (1999). Persepsi terhadap Pendidikan Islam (Akhlak Islamiah) dan kaitannya dalam pembentukan akhlak remaja: Satu tinjauan di Kolej Islam Melaka. Latihan IImiah. Universiti Teknologi Malaysia.

Khadijah Abdul Razak. (2009). Pembentukan insan beraklak mulia daripada persepektif falsafah pendidikan Islam. Prosiding Wacana Pendidikan Islam Siri 9 (peringkat Nusantara). Indonesia: Institut Studi Darussalam Gontor.

Mardzelah Makhsin. (2012). Hisbah dan Penghayatan Akhlak Murid Sekolah Menengah. Tesis PhD. Universiti Kebangsaan Malaysia.

Mohd Arif Kasmo. 1988. Pembangunan akhlak pelajar di sekolah agama. Jurnal Pendidikan, 23: 119-127.

Mohd Razali Deraman. 2007. Pengaruh budaya terhadap akhlak remaja Islam: satu kajian di Kota Bharu, Kelantan. Disertasi Sarjana Usuluddin: Jabatan Sejarah dan Tamadun Islam, Akademi Pengajian Islam, Universiti Malaya.

Siti Norlina, Muhammad 1997. Perubahan nilai-nilai moral masyarakat Islam: Satu kajian di Wilayah Persekutuan. Disertasi Sarjana Usuluddin. Fakulti Usuluddin, Universiti Malaya, Kuala Lumpur.

Wan Mohd Noor Wan Daud. 2005. Falsafah dan amalan Pendidikan Islam Syed M. Naquib al-Attas. Kuala Lumpur: Penerbit Universiti Malaya.

Yaljin, Miqdad. (1977). al-Tarbiyyah al-akhlaqiyyah al-Islamiyyah. Al-Qaherah: Maktab Al Khanji.

Zaharah Hussin. (2008). Pembinaan kandungan kurikulum pendidikan akhlak untuk latihan perguruan Pendidikan Islam. Tesis Doktor Falsafah. Fakulti Pendidikan, Universiti Kebangsaan Malaysia, Bangi.

Zuhair, Muhammad. (1995). Pendidikan iman dan akhlak dalam kekeluargaan. Johor: Perniagaan Jahabersa. 